\title{
Arte y Poder en la historia
}

Rodolfo Pastor Fasquelle

\section{Resumen}

El poder público establece, de manera más o menos transitoria o sostenida, las condiciones objetivas para el desarrollo del arte. El poder específicamente permite que se produzca el tipo de especialización que impulsa el desarrollo dinámico del arte "profesional", como un oficio, al que el artista puede dedicarse, asegura las condiciones en las cuales se puede financiar, conseguir materias primas e importar innovaciones. De ese modo permite que el arte evolucione. Aunque también puede ser muy conservador el arte oficial, tiene esa inclinación o inercia, de conservar. Hablemos pues del arte que, desde los albores de la historia, se hace a solicitud del poder y para sus fines, casi todo el arte, porque la mayoría de los fenómenos artísticos de nuestra civilización se originan en esa demanda del poder: político, eclesiástico o económico.

Palabras Clave: poder público, especialización, arte del poder.

\section{Abstract}

Public power establishes, in a more or less transitory or sustained manner, the objective conditions for the development of art. Specifically, power allows the emergence of a type of specialization that drives the dynamic development of "professional" art, as a trade, to which the artist can dedicate, it ensures the conditions for financing, obtaining raw materials and importing innovations. In this way it allows art to evolve. Even though official art can be very conservative, it has the inclination or inertia to preserve. Let us talk then about the art that, since the down of history, is made at the request of power and for its own purposes, most art, because most of the artistic phenomena of our civilization originate from the demand of power: political, ecclesiastic 0 economic. .

Keywords: public power, specialization, art of power.

Rodolfo Pastor Fasquelle, Museo de Antropología de San Pedro Sula, Honduras. 


\section{INTRODUCCIÓN}

El poder y el arte son productos sociales ${ }^{1}$. Hay conceptos culturales diversos pero definamos arte como la invención originaria, lo que nos separa del mono desnudo: la producción de expresiones y relatos, imágenes y representaciones. La facultad de comunicación fuera de la naturaleza. Y definamos poder como facultad elemental 0 fuerza de autoridad para hacer, obligar a hacer o impedir que se hagan "cosas", sin olvidar que también es "poder" la capacidad de resistir una imposición. Ahora ¿cuál es "El Arte del Poder"? ¿Arte hecho para el poder 0 arte que tiene poder? ¿El uso que el poder hace del arte 0 el arte de ejercer el poder? Todas son interpretaciones del titulo sobre el que me piden hablar. Interpreto que puedo escoger. La historia del arte universal ofrece un observatorio privilegiado para profundizar en el tema.

El arte (en Altamira, treinta mil años antes de Cristo) es previo a la polis, pero el poder es previo al arte. No lo necesita. El macho dominante de la tribu tiene poder antes que nadie tenga arte. El escritor israelita, $\mathrm{Amos} \mathrm{Oz}$, convocado a disertar sobre "La imaginación del Estado", empezó declarando que "el Estado carece por completo de imaginación" y yo aseguro que el poder no necesita de la imaginación y menos del arte... a menos que quiera ahorrar sangre, sudor y lágrimas y muchas veces al poder no le interesan esos ahorros. ¿Qué arte le hizo falta a la Guerra contra Irak, quintaesencial ejercicio del poder en la actualidad? ¿Cuál arte le falto a la dictadura militar latinoamericana?

Existe desde siempre un arte fuera del poder, cierto tipo de arte, fuera de una estructura de poder formal; un arte "libre" que puede alcanzar cierto refinamiento². Como la milenaria pintura de los aborígenes australianos, con asombrosas representaciones de una fauna mítica; la cestería del indio amazónico, el arte de los huicholes con sus visiones coloridas o el arte rupestre del Caribe, que abunda en Honduras ${ }^{3}$ y la literatura oral de los sumo-tawakas y tolupanes ${ }^{4}$. Esas manifestaciones artísticas no requirieron de un poder político y sin embargo reproducen la cultura de esos grupos, codifican y trasmiten una cosmovisión, un sistema complejo de valores y una forma de comportamiento derivado. Pero ese arte es estático. Pasan siglos y no cambia, no evoluciona. Es un arte del eterno retorno en sentido estricto, autosuficiente.

\footnotetext{
${ }^{1}$ No hay arte sin forma ni fuera de la sociedad y el "poder" extra social (de la naturaleza o de los dioses) es una metáfora antropomórfica mal entendida.

${ }^{2}$ En el sentido claro de libre de un poder formal que lo restringe. ¿Puede ser mas refinado el arte que en Altamira?

${ }^{3}$ Alejandro Figueroa, "El Arte Rupestre en Honduras" IHAH, 2006.

${ }^{4}$ Anne Chapman, Héctor Leyva y recopiladores
} 
Por otra parte, la invención de la historia -y los mayas, he dicho en otro sitio inventaron una historia ${ }^{5}$ exige una nueva concepción del poder e impulsa una nueva dinámica del arte. El poder publico a la vez que cataliza la historia, propicia una dinámica social y requiere de la correspondiente evolución del arte. Y entonces en la civilización, el arte evoluciona para el poder, deviene "oficial". El poder descubre la fuerza del arte, lo instrumentaliza para sus imperativos, lo convierte en arte del poder o lo censura. ¿Sera preciso advertir que ni el arte ni el poder son infalibles?

\section{ARTE PARA EL PODER}

El poder público (la formación estatal, primaria o evolucionada) establece, de manera más o menos transitoria o sostenida, las condiciones objetivas para el desarrollo del arte ${ }^{6}$. El poder específicamente permite que se produzca el tipo de especialización que impulsa el desarrollo dinámico del arte "profesional", como un oficio, al que el artista puede dedicarse, asegura las condiciones en las cuales se puede financiar, conseguir materias primas e importar innovaciones. De ese modo permite que el arte evolucione. Aunque también puede ser muy conservador el arte oficial, tiene esa inclinación o inercia, de conservar. Hasta que llega un Amarna o un $13 \mathrm{Hel}$. Y conservador o revolucionario el poder se ostenta con gran arte. De hecho los florecimientos artísticos se han vinculado siempre a momentos de madurez de un sistema político que los patrocina.

Hablemos pues del arte que, desde los albores de la historia, se hace a solicitud del poder y para sus fines, casi todo el arte, porque la mayoría de los fenómenos artísticos de nuestra civilización se originan en esa demanda del poder: político, eclesiástico o económico. Desde él más antiguo templo egipcio hasta los murales de Rothko para Las Cuatro Estaciones.

Saquen de la lista el arte que no se origina en la demanda del poder y ¿qué queda? Porque al final, para hacer arte se necesita quien lo compre o patrocine y los recursos los controla el poder. Y si no quieren responder a esa demanda, si quieren ser "libres" y complacer solo a su imaginación, como insistía Gauguin, los artistas pueden hacer otra cosa: pueden ir a la guerra para expandir o defender el poder o sembrar y tributar sus excedentes a los poderosos, pueden construir canales

\footnotetext{
${ }^{5}$ Junto con una matemática y una jeroglífica. Y la historia es arte. Pastor Rodolfo, La Escalinata de los Jeroglíficos como invitación a la historia, presentación ante el Seminario de Harvard sobre La Escalinata, Umbrales, 2006. ${ }^{6}$ Incluso la censura y la represión condicionan la creación de un arte superior al promovido o sostenido desde el poder, dice
José A. Funes en el margen
} 
interoceánicos o morirse de hambre y desesperación; pero no podrán hacer arte, sin un mínimo de condiciones objetivas de sustentación. E inicialmente, según un patrón general, el primer arte oficial se emplaza en el templo porque el primer estado es teocrático. Cuando la religión justifica el poder ${ }^{7}$.

Resulta obvia la correlación desde el medioevo tardío entre el proceso de construcción de las monarquías europeas, la codificación de las lenguas vernáculas por parte de las literaturas y la edificación de sus grandes catedrales. Y Víctor Hugo, me dice Viel, escribe sobre "la catedral como instrumento por excelencia de propaganda", antes del libro.

En el mundo maya y también en la civilización clásica Occidental, pasando por el Renacimiento y por la formación de los modernos estados e Imperios, el artista vive en un mundo estructurado por el poder y sirve a sus fines. Lo mismo sucede bajo el antiguo imperio egipcio o el español del s. XVI; en Atenas bajo Praxiteles, bajo los Médicis en Florencia o en la antigua Copan. Y el gran arte prospera y evoluciona en cuanto que el poder que lo ampara se reproduce. Quizás también esa evolución explica porqué y como el arte se deja instrumentalizar y usa distintas modalidades del "poder" en su beneficio".

En la antigüedad, según H.G. Wells, los "intelectuales" se independizan de la teocracia cuando se desarrolla el Estado, porque: el palacio les brinda un refugio con respecto al templo. Y en el palacio, se forja una nueva relación simbiótica entre el intelectual, el letrado que ya no es sacerdote, el artista y el poder secular. La secularización del poder y la secularización del arte son procesos paralelos que se influyen el uno al otro y se necesitan. (En el caso maya, quizás nunca se produjo esa diferenciación, pero el punto sirve para profundizar...) Si el artista trabaja para el poder político a nadie debería sorprenderle que la Acrópolis de Copan sea un complejo arquitectónico dedicado a la exaltación de los clanes gobernantes y a servir de escenario para los ritos del poder. Aunque, estando empapadas las relaciones del poder con la religión, ese arte se exprese en términos fundamentalmente cosmológicos: porque la Acrópolis es, a la vez, montaña sagrada, florida, es el huitz, divino monstruo de la tierra.

\footnotetext{
${ }^{7}$ Hace falta rastrear la relación entre el establecimiento del cristianismo como religión oficial del Sacro Imperio Romano y la construcción de las catedrales bizantinas, que resucitaron -cristianamente- el poder y arte de la antigua Roma.

${ }^{8}$ Como en el caso de la relación del poder y la religión, la que se da entre el arte y el poder es de mutua instrumentalización y complicidad.
} 
Tampoco (debería sorprendernos) que la Escalinata de los Jeroglíficos sobre la cual he escrito con admiración sea fundamentalmente un monumento a la historia del poder y que las estelas representen a los poderosos reyes de Copán, en el ejercicio del poder, en la ceremonia por excelencia del poder, que es el sacrificio de sangre ${ }^{9}$. Los hombres del poder (sacerdotes, guerreros, administradores) son, desde siempre, no solo grandes patrocinadores sino sujetos de la representación artística y ellos mismos artistas: arquitectos y literatos. E incluso tiene la gente de poder alguna exclusividad o monopolio sobre ciertos tipos prestigiosos de arte: igual la arquitectura del Rey Pacal que la lírica de la elite tezcucana (de Nezahualcoyotl o Nezahualpilli) o la orfebrería de los reyes mixtecos, por dar ejemplos de la antigua Mesoamerica cuyo rey arquetípico Quetzalcoatl es a la vez un dios inventor de las artes. Pero sobre todo, el poderoso es un artista del poder que se rodea de artistas que lo representan....En efecto el ejercicio del poder puede ser elevado a forma de arte.

\section{La escenificación artística del poder}

Helos ahí a los reyes, barbados con la sangre de su autosacrificio facial, vestidos o enmascarados con la piel del desollado, con el cuchillo del sacrificio en sus brazaletes. En medio de la fanfarria y el estruendo de las trompetas y los tambores de madera y de piel, y las flautas y chirimías y sin duda la caramba y caparazones de tortuga que acompañan las procesiones. El rey sacrificador es un artista, un farsante que escenifica el poder. Lleva tocado de Jaguar. Se viste con objetos de arte, de plumaria y tejidos primorosos, de lapidaria en obsidiana o en jade, participa en un ceremonial que es teatro y mima, acompañado por artistas y el arte del escultor registra y documenta esa escenificación: el triunfo, la trasmisión dinástica, la investidura y la boda. Haciendo su danza, el rey bailando su "son" sobre la plataforma. Igual en Europa. El Circo es arte también y el anfiteatro; también en ellos se representa originalmente la obra por excelencia, elemental del poder, la ejecución publica, preferiblemente de los políticamente peligrosos. El formalísimo Auto de Fe acompañado de música gregoriana y utilería artística-religiosa.

El ceremonial de la Corte es una forma de arte. Secundario, efímero y, si se quiere intrascendente, pero arte al fin, que establece el orden del favor del poderoso, al

\footnotetext{
${ }^{9}$ Los sacrificios justificaban ideológicamente el poder, los auto-sacrificios del rey y los sacrificios de sus victimas legitimaban el poder del linaje gobernante. Al $13 \mathrm{Hel}$ se le representa vestido con la piel del desollado. Casi todas las estelas representan a casi todos los reyes como sacrificadores con arte menos grotesco, pero esta imagen quiere representar al rey como el colmo de piedad, de un rito que por lo demás es de renovación cósmica y renovación del poder.
} 
mismo tiempo que la solemnidad del poder. Por eso también la Corte requiere de artistas y de maestros de ceremonia. En Terra Nostra, Carlos Fuentes representa a la Corte-espectáculo de los Austrias. Piensa en las procesiones de entrada del Virrey a Lima o México en el s. XVII, o la de un Presidente de la Audiencia a Santiago, Guatemala, que pueden vislumbrarse en biombos pintados y que documentan el riguroso protocolo, la jerarquía de los personajes y el tipo de vestidos y joyas permitidos a cada cual. $Y$ no solo en el antiguo régimen. Clifford Geertz y sus alumnos hablan de los "Estados Teatros" en referencia a los rituales de las elites gobernantes en el África y la India medieval y en el Bali del s. XIX ${ }^{10}$. Y el ceremonial que sobrevive de las tomas de posesión de los gobiernos nacionales y democráticos heredan aquella pompa en toda su vacuidad y ansiedad "artística".

Buscando ser astuto, el poder político descubre la utilidad del arte, el ahorro rentable que puede conseguir, se apropia del arte y del artista, los ampara y pone en escena y en proporción a su lucidez, ilustración y posibilidad, los consiente. Premia al artista favorito 0 al que esta de moda con beneficios, contratos, honores. Como la Cruz de Calatrava que Velásquez pinta sobre su pecho en Las Meninas o él titulo nobiliario para un rockero. O le suspende el patrocinio cuando el artista entra en controversia, por buenas o malas razones con el poder ${ }^{11}$. Nunca fácil esa relación.

Genera una ambigüedad. Leonardo muere en brazos del rey francés. Otros artistas mueren perseguidos. El teatro de Shakespeare esta casado con la figura de Isabel I, Cervantes (concreción perfecta de la gramática imperial de Nebrija) no se entiende sin Felipe II, aunque no fueran los artistas empleados ni favoritos siempre del rey o, como en él ultimo caso, sucediera lo contrario y el artista fuese critico solapado. "Poeta fanfarrón" se llama a sí mismo cuando goza el privilegio del bufón para burlarse del túmulo funerario de Felipe II, que encarna la quintaesencia del arte oficial'12. No sé si a Cervantes se le negó el permiso para "pasar a Indias" por el

\footnotetext{
${ }^{10}$ Geertz, C., Negara: El Estado Teatro en el Bali del s. XIX, Paidos, 1999.

11 Pienso en el Rembrandt que según explica Schama The Power of Art fue alejado del patrocinio del arte republicano de Holanda en el siglo XVII porque su estilo evolucionó más allá del gusto prevaleciente. Y en su "Sátira de la critica del arte" $Y$ en el medallón que cuelga de la cadena sobre el pecho de su Aristóteles", con un retrato de Alejandro Magno.

12 La construcción del "túmulo" funerario era una obra de arte del poder, como las efímera plataformas ceremoniales para inaugurar gobiernos, que gracias a Dios, no se conservan, pero en cuyos diseños compiten renombrados artistas y farsantes y el túmulo era una forma de arte publico que se siguió practicando hasta el final de la época colonial (hay túmulos de Carlos III) cuando --igual que en el ceremonial maya - el ceremonial de la Corte era una escenificación.
} 
soneto que escribió burlándose del túmulo mortuorio o si se burló del túmulo porque no le dieron el permiso. Pero aquí da igual.

La Corte de Felipe IV, al mando del Conde Duque de Olivares, ostenta a Góngora y al poeta Luis Mendoza, alquila mientras puede y después, cuando ya no puede controlarlo, encarcela a Quevedo, al mismo tiempo que patrocina el teatro de Lope de Vega, su dramaturgo favorito, también colecciona las pinturas de Peter P. Rubens y ennoblece al pintor de la Corte, que pinta los retratos ecuestres del Rey y del mismo Olivares, ostentando su control de la bestia encabritada con una mano en la rienda, imagen que-según Schama- ha simbolizado desde siempre al poder crudo $^{13}$. El propio Conde Duque, que tanto combatiera otros lujos ociosos, por inmorales, anima al rey imberbe en su gusto por las artes, protege a historiadores a quienes había desestimado su antecesor y se apena al tener que reprimir a Quevedo cuando este se vuelve peligroso ${ }^{14}$. Pero los conceptos del arte oficial evolucionan casi siempre de manera impredecible. El arte del poder es voluble y tornadizo.

El "Patronato Real" de la Iglesia en la primera América fue, en primer lugar, un patronazgo de las artes misioneras (de los conventos fortalezas) en tierra de infieles, del arte religioso, entendido como instrumento de conquista espiritual, y de dominación. Así, la estética virreinal se vincula a la teoría del "Pacto Colonial" ("el justo y cristiano gobierno asegura la libertad y el derecho") el cual luego se convierte en el fundamento ideológico de la Independencia, cuando aparece en América, al menos documentado, un arte de la rebelión, de La Revolución: La Historia de Clavijero y la propaganda de Fray Servando Teresa de Mier. Y de ser La Virgen quien consigue el consentimiento de las masas indígenas para el gobierno cristiano, Guadalupe pasa a icono por excelencia de la guerra de Independencia. Serge Gruzinsky explica: las masas se apropian de las imágenes del poder colonial

\footnotetext{
${ }^{13}$ Schama, Simon, The Power of Art p.365. Al menos desde tiempos grecorromanos, el caballo dominado acaso simboliza al colectivo.

${ }^{14}$ Acaso Quevedo había caído victima del otro juego de poder; pudo tener otras razones; convengamos que no tenía ninguna cuando recurría a la insinuación racista antisemita contra el Conde. H. Eliott, El Conde Duque de Olivares.
} 
y las convierten en imágenes de la rebelión, en instrumentos simbólicos de la resistencia ${ }^{15}$. Igual sucede con La Cruz y la imagen del Cristo entre los tzeltales ${ }^{16}$.

El arte codifica una serie de ideas justificatorias del poder, las vuelve transparentes, las carga de emotividad, las comparte y divulga. Así, las convierte en varas de medir con las que a menudo no salen bien evaluados quienes las predican como justificatorias del poder, de modo que terminan por parecer subversivas. El artista puede tener 0 no profunda conciencia de ese poder de transformación del arte. Y cuando la relación se complica, surge una tensión entre arte y poder.

Existen antecedentes antiguos. La destrucción del arte de Amón por Akhenaton, y luego la destrucción del arte de Amarna por los sucesores del faraón hereje. ¡Los aztecas queman los códices toltecas, para anular el antecedente que después invocan! ¡Los españoles destruyen las estatuas y queman los códices en el México conquistado, cuyo esplendor imperial evocan después! Pero también Shi Huang-ti (259-210 a.J.C.), el fundador de la dinastía Ch'in quema los rollos de las anteriores para fundar su dinastía como primera. Con la destrucción de la escultura y pintura religiosa en La Reforma, esos ejemplos ilustran un reiterado enfrentamiento del poder y el arte, inspirado en el mismo principio de la destrucción de las estelas maya. Son pistas que hay que seguir, de una contradicción profunda, antigua y moderna, universal.

\section{Sobre el poder del arte frente al poder: evolución moderna}

Las ideas que se vuelven contra sus inventores se manifiestan en arte que se vuelve contra sus patrocinadores. Aun en el pensamiento primitivo, el arte contiene o conjura un poder intrínseco, mágico, suyo propio. En una exhibición de arte de los indios norteamericanos en El Peabody ("Arts of Diplomacy"), el Curador Castle McLaughlin explica que ha tenido que manipular los objetos (eg. las pipas de la paz) para despojarlos del poder de que están dotados. Y los arqueólogos suponen que a

\footnotetext{
15 Y los realistas se refugian en La Virgen de Las Mercedes. Gruzinsky, Serge, La Guerra de las Imágenes. Algo semejante va a pasar con la reivindicación de los mitos republicanos en el México Revolucionario del siglo XX. Igual se podría hablar de la instrumentalizacion de las imágenes públicas (productos del arte de su época) de Marti en Cuba o de Morazán en El Salvador y Honduras. Otra pista, de obligado seguimiento.

${ }^{16}$ Vid Bricker, Victoria, El Cristo indígena, el rey nativo: El sustrato histórico de la mitología del ritual de los mayas, FCE, México, 1989. Que estudia una de muchas rebeliones milenaristas en la zona maya de la época colonial.
} 
las antiguas estelas mayas se las despojaba de su poder, después de la muerte de un rey, matándolas, mutilándolas, desfigurándolas, rompiéndolas, enterrándolas ${ }^{17}$.

Porque tiene poder el arte puede entrar en contradicción con el poder público que lo patrocina. $Y$ tiene poder porque compromete con su representación, nos ubica, nos recuerda, nos despierta, libera nuestra imaginación y ennoblece el sentimiento (pathos), lo "purifica": él más noble sentimiento que es el amor y la fundamental caritas o humanitas, la reciproca empatía general que nos debemos. Puede conducirnos de la hybris a la catarsis decían los griegos. Puede burlar las exigencias y cánones del poder, el arte maya incluso! ${ }^{18}$. En The Power of Art, Simón Schama recuerda que el gran arte tiene una especial capacidad para sacudirnos, quizás puede ahorrarnos la tragedia que representa, a lo menos puede explicárnosla.

Una película reciente -producción franco alemana, titulada "Feliz Navidad" en francés-- ilustra una serie de incidentes ocurridos un día de Navidad durante la Primera Guerra Mundial en un lugar no especificado de La Línea Maginot, donde las trincheras de los ejércitos enemigos se ubicaban a veinte metros unas de otras. $Y$ en donde el accidental intercambio navideño de manifestaciones artísticas, de un tenor y una soprano alemanes, que cantan noche blanca y las gaitas escocesas y las dulzainas francesas terminan por precipitar una tregua no autorizada por la autoridad superior y una serie de intercambios de regalos, vinos por cervezas y scotch.

Esa capacidad subversiva del arte puede ser un peligro advertido y un reto inaceptable para el poder constituido o el que busca establecerse a costa de otros derechos. Tradicionalmente, el conflicto no inhibe la convivencia. El poder del arte contra el poder esta ahí, dentro de la tradición, en el arte humanístico clásico (en la tragedia de Ifigenia o la de Antigona o Las Troyanas) y Arechavala piensa siempre en los grandes artistas, pero resurge en el arte moderno como el nuevo paradigma.

El arte va a ser cada vez más subversivo en el mundo moderno, desde la ironía del Siglo de Oro (Erasmo, Cervantes y Quevedo) y las rebeldes pinturas de Rembrandt hasta la confrontación abierta de Picasso y Ubu Roi, pasando por Goya y Goethe ${ }^{19}$.

\footnotetext{
17 El sociólogo chileno Lipchutz interpreto esa destrucción como signo de rebelión, cuando significaban más bien una renovación del poder. El equivoco todavía circula.

18 Según Viel en Copan, el arte de "Los Sapos" pudo ser un arte popular que respondía en forma subversiva contra el rígido canon del Grupo Principal. Expresa así una idea al menos insinuada por su maestro Claude Baudez en el Seminario sobre Religión Oficial y Religión Popular, I.H.A.H. Copan 1997.
}

${ }^{19}$ Quien exalta la rebelión antes de convertirse en protegido y funcionario de Weimar. 
Con la modernización social, el poder de compra se diversifica, el ciudadano puede comprar cada vez más lo que no compre el poder publico. No sé si es una conquista de la modernidad, de la democracia, que comparte el poder económico y político, antes que pueda repartir de manera igualitaria el gusto educado. Pero el artista se independiza -ahora del palacio- cuando surgen el poder económico de la burguesía (que también es subversivo dice Marx) y el de la academia independiente. El poder de compra de la burguesía induce desde el Renacimiento el arte hecho para el banquero y el comerciante, que se ennoblece en Rembrandt, quien igual desarrolla una relación ambigua y tirante con sus nuevos patrocinadores. Quizás el ejemplo por excelencia del cambio en la relación es David. Que inicia su carrera patrocinado por el Rey al que luego ayuda a degollar como primer artista parlamentario, jacobino y que termina pintando, servil "la gloria" de Napoleón ${ }^{20}$.

El rompimiento del arte con el poder cristaliza (como tantas otras cosas) a fines del s. XVIII. Y se observa primero en la literatura (de J. Swift) y en la filosofía (o acaso olvidamos que la filosofía es una de las artes, con la historia) que va a desmontar los fundamentos ideológicos de la monarquía absoluta pero también de los sistemas sociales que denuncia, el esclavismo primero. El singular William Blake ya representa ese movimiento. Desde el Romanticismo se les llama "liberales" a las artes y el arte moderno se constituye en custodio del derecho, paladín de la libertad y de la tolerancia y en reserva ética, y sigue siéndolo, incluso cuando confronta la hipocresía y los falsos valores que lo denuncian como libertino desde la inmoralidad del poder.

El arte moderno se plantea esa ruptura política y estética abiertamente. Goya es el ejemplo clásico del artista que, salido del privilegio, termina exiliado y luchando contra el poder ${ }^{21}$. Desde Goya (desde el 3 de Mayo hasta "los desastres de la guerra") esa visión torna subversiva. En la rebelión romántica asoma una visión personal, pre impresionista, alborada de una nueva forma de ver y hacer arte. De ahí solo hay un paso al Guernica de Picasso. La pintura moderna, dice A. Malroux, "comienza después de Goya". Pero en general los grandes románticos van a ser

\footnotetext{
${ }^{20}$ Vid Simón Schama, El Poder del Arte, él capitulo dedicado a David, tan dolorosamente esclarecedor. Y en cuanto a David, es el primer artista diputado, el primero en el foro.

${ }^{21}$ Goya colabora como artista de la Corte de Carlos IV, con los bocetos para los tapices decorativos del palacio y -luego- con los retratos oficiales, paradigmas del arte del poder y que, luego, en Burdeos, exiliado, se convierte en un artista ideólogo de la Revolución Liberal contra el absolutismo monárquico.
} 
rebeldes, como Beethoven y Dostoyevsky, y Federico Nietzsche llama al arte "la actividad metafísica fundamental", "epitome de las facultades creativas" 22.

Van Goh, Gauguin reivindican luego una independencia del arte que llega hasta el Picasso y los expresionistas: sus gritos y sus angustias. Pero en primer lugar su rechazo al poder. En el proceso hacen tabla rasa de un milenio de tradición evolucionada a la sombra del poder, para democratizarse y reivindicar derechos y caprichos. Con el dadaísmo y el surrealismo la ruptura es total, con Braque y Picasso. Y con la literatura de vanguardia.

Picasso no pinta al poderoso ataviado a caballo, si no al niño imberbe y desnudo guiando, sin brida, a un jaco que volea la mano encascada y pinta el Guernica sin temor de irritar al Tercer Reich y así, en vez de republicanos o comunistas, nos hace pacifistas. El arte moderno entonces induce una conciencia crítica contra el poder, como hace el poema de Allan Ginsberg sobre la bomba atómica "americana" o el documental contra la guerra de Irak de Michael Moore ${ }^{23}$. Y el poder se incomoda. Los nazi acosan a Picasso y Hitler odia al arte de vanguardia de su época (el abstracto expresionismo) tildándolo de "decadente" y patrocina la más banal de las plásticas decorativas, al tiempo que saquea los museos de países ocupados. La dictadura guatemalteca exilia a Monterroso, la soviética persigue a Solyenitzin.

Es porque el arte tiene poder o capacidad para contradecirlo que el poder lo persigue. La antigua contradicción se reedita. Interesan igualmente a este respecto el iconoclasia de Estado y la revolucionariia así como los abanderamientos de un arte nuevo comprometido con este o aquel proyecto. Las revoluciones pueden ser destructivas incluso de artes que no se proponen cuestionarlas, pero que representan una contradicción implícita.

La Revolución "Cultural" China, que también adulteraba las fotografías del poder, ha sido quizás en nuestros tiempos la más destructiva del arte y de los artistas. Pero ha habido persecución del arte (de distinto signo ideológico) en América Latina, igual en Cuba que en Argentina. En el Afganistán de hace apenas diez años, los Talibán perciben la fuerza (el poder) de los budas esculpidos en la montaña (porque el arte antiguo también puede subvertir los nuevos paradigmas) y

\footnotetext{
${ }^{22}$ Guervos Santiago, "Arte y Poder, aproximación a la estética de Nietzsche", Trotta, Madrid, 2004

${ }^{23}$ No es gratuito el hecho de que Ginsberg se identifique con Blake, místicamente.
} 
disponen atacarlos con el poder de fuego de sus aviones de guerra. Los iraquíes, con ayuda de los "aliados", destruyen las estatuas de Saddam, como antes en la ex Unión Soviética sé habían destruido las estatuas de Stalin y en Irán las del Sha, etc. Porque además puede tener sentido que los libertos destruyan la imagen monumental de un hombre que los ha humillado y tiranizado durante décadas en aras de su megalomanía. Cuando la ruptura esta a la vista, el poder busca cooptar al arte rebelado, igual en el México del PRI que en la Unión Soviética y en cuanto no lo consigue completamente, sustituye al artista comprometido con el mercenario y con "el espectáculo", el Circo redivivo. Muchos incluso buenos se acomodan o resbalan: Picasso termina, dice Schama, jcomo "póster boy de Stalin", cuyo acólito es el gran Pablo Neruda! ¿Gazapos? ¿Acaso cuando invocan la moral superior del socialismo, los modernos paladines de la libertad y la justicia, son menos cómplices del crimen que el escultor maya?

\section{La fragilidad del arte frente al poder}

Por el papel difusor de los medios de comunicación, en nuestro tiempo ¿alcanza a darle, para bien y para mal, un prestigio sin precedente y un nuevo poder? "Nada mas que el arte". ¿O más bien se corre el riesgo de que se debilite el arte, pierda poder, suplantado con un placebo, subordinado al entretenimiento y prevalezca el nuevo circo mediático?

El problema pareciera ser su fragilidad, su vulnerabilidad del arte frente a la manipulación del poder y la eterización o alineación de los medios. El pobre arte necesita que le pongás atención, que escuchés incluso con el oído interior y que lo mirés con el otro ojo de tu mente, iluminado; y necesita que pienses para ejercer su poder. Necesita que te abras a él y que penetres en él, en su densa magia cautivante. Y si no, no funciona, no puede...

Un activista local de la cultura, el Dr. M. Zapata confesaba hace unos días, en un video documental, que caminó durante muchos años, todos los días, frente y a un costado de la Catedral de Comayagua, sin reparar en, ni valorar la abundancia de su arte, la riqueza que tenía en sus narices, pero que no "veía" ${ }^{24}$. Al arte hay que verlo.

\footnotetext{
${ }^{24}$ Un arte que estuvo ligado alguna vez al poder colonial y de la Iglesia, que después inspiró independentistas y que hoy tiene poco que ver con el poder, porque esta no es ya una sociedad cristiana pero sigue teniendo el poder de hacernos cavilar. Eso les paso a los centroamericanos por siglos con el arte maya, desdeñado por pagano, gentil y que no estaba simplemente en la mira. Era el mismo arte que hoy idolatramos pero no lo valorábamos, de forma que el propietario rural le vendió las ruinas a J. L. Stephens por \$50 dólares en 1838.
} 
Tienes que volver sobre él, como aconseja Borges que vuelve la gente sobre los textos para otorgarles el status del clásico. Entonces, cuando lo vuelves a ver, aunque no suscribas el mensaje, su belleza te cautiva. $Y$ hace algo mas, te ilumina con luz propia. Su código histórico adquiere otro significado, el que le da tu reflexión crítica. ¿Será posible que, cuando ya no te puedan redimir, por tu falta de fe, el Buda Maitreya ni el Jesús Crucificado, destruidos (como el Cristo carbonizado en la Galería Nacional) ya sólo recordados, todavía te puedan redimir sus imágenes conmovedoras? ¿Será posible que esas cosas que se han vuelto invisibles en las imágenes sean al fin lo que te puede salvar?

\section{Los poderes inadvertidos del arte}

Entonces, cuando el poder condena y desbalaga el arte redime y compromete. Compromete porque redime, por el gozo absoluto que proporciona. Sin compromiso, el arte es una impostura. No se trata por supuesto de compromiso político panfletario, ni tan solo de un compromiso del artista trasmitido directamente a un receptor. El arte libera, incluso cuando atestigua o proclama la tiranía. Porque no tiene solamente el significado intencional de su autor, patrón, tiempo y contexto; si no tantos más como después le damos y, en ese sentido, es más duradero que el poder. Post facto, el arte se recarga de poder nuevo, de sentido, con la experiencia. El artista trabaja para su posteridad igual que el héroe, mientras él poderoso sólo trabaja para la próxima crisis.

Seguro que el artista que esculpió a 13 Hel de Copán como un sacrificador, vestido con la piel desollada de su victima no se propuso mas que elogiar a 18 Conejo, quizás ya desquiciado, alabando su piedad extrema. Al pintar al Emperador cruzando Los Alpes David tampoco se proponía otra cosa que adularlo. Pero, en ambos casos, a nosotros, esas imágenes nos sirven para liberarnos, de la superstición y del mito que quieren suplantar a la historia y el arte. Dieciocho Conejo queda desenmascarado como un psicópata sanguinario ${ }^{25}$. Y puedo invocar la imagen de David pintando contra el artista cortesano zalamero que deja un pulido recuerdo de su propia bajeza, siendo un grande, contra la de Picasso adulando a Stalin. ¿Cuál es entonces la circunstancia complementaria que tenemos que poner para que el arte pueda liberarnos? ¿Cómo defenderlo contra la insensibilidad, mostrarlo,

\footnotetext{
25 Recién en la campaña política que eligió al actual Presidente invoque la imagen del rey maya "sacrificador" en esa estela para representar a su entonces rival del actual Presidente, quien proponía la pena de muerte como lema. E igual puedo usar la imagen ridícula de Napoleón satirizada sin proponérselo y con sus instrucciones del Emperador por David o Poussin, cuando cualquier megalómano se me pone enfrente
} 
ponerlo en escena, procurarle atención, enseñarle a la gente a verlo con sus múltiples sentidos, con la atención que requiere para que funcione, para entenderlo y descubrir su sentido redentor?

\section{Los retrocesos del poder y del arte ¿explican su complicidad?}

Hay ocasiones en que las sociedades involucionan de tal forma que el poder público retrocede, sé torna elemental y deviene primitivo o primordial ${ }^{26}$. El poder público renuncia al arte, que que es caro y deviene un lujo si estas dispuesto a gobernar por la fuerza. Porque los cambios sociales paradigmáticos suponen cambios en los códigos; y la transición (de un paradigma a otro) puede prolongarse y el poder derribado no siempre se reconstituye con igual eficacia. Entonces el poder incluso persigue al arte que no puede controlar. Pienso en el Mulato de Acero Ferrera quemando la biblioteca del "hereje" Herrera. Y en todo caso, se pierden las condiciones para el desarrollo del arte, de las artes y las humanidades.

Después de La Caída del Maya Clásico o después de la caída de Roma, el arte retrocede. Del mismo modo, la escultura del bajo Medioevo parece una caricatura torpe de la gran escultura clásica y la ultima estela de Yax Pasaj es una pena: chaparra y tartamuda, falta de sentido de proporciones y despojada de riqueza iconográfica frente a las magnificas esculturas del 15 Hel. Quizás esas decadencias explican por que el arte se aferra al poder. Explican también indirectamente los movimientos que después procuran "renacimientos" artísticos y políticos, de Roma y Tollan, renacimientos, que se vinculan a nuevas articulaciones de poder y apelan al "antecedente"27.

Luego del colapso del poder que lo potenciaba, el artista no encuentra ya un espacio para el arte despreocupado en cuanto que el Estado, disminuido si sobrevive, involucionado, tampoco lo requiere ni esta dispuesto a pagarlo y a veces no tiene con que. El arte se vuelve artesanal y se privatiza; se vuelve íntimo. Y el artista tiene que ingeniárselas para ganarse el pan con otro tipo de cliente o de sudor, que

\footnotetext{
${ }^{26}$ Algo de ese tipo pasó en América Latina, de distintas maneras, luego de las guerras de "La Independencia": larga y profunda crisis socio política y económica (las minas están inundadas, los ejércitos arrasan el campo, el comercio está interrumpido) que dura por lo menos desde el 1810 hasta la consolidación de las nuevas dictaduras de 1840 . Pero el poder sigue siendo elemental -después- en esa república hondureña regida por varias constituciones desde 1840 hasta La Reforma Liberal.
}

${ }^{27}$ Ver.... sobre Las Inscripciones en el templo de La Escalinata en Fash, A History of Copan. 
el de su frente. $Y$ pueden pasar generaciones que no producen arte 0 al menos aquel arte.

Se da un paso atrás o más. En Honduras, fue más prolongada que en otros países la crisis posterior a La Independencia. Y entonces la producción artística (rica en la época colonial) se desploma y aparece un arte naif o un nuevo primitivismo ${ }^{28}$. Quedan del momento inicial -después de La Independencia- retratos numerosos de personajes de la burguesía local o representaciones religiosas primitivas pintadas o talladas y, en nuestro caso, el gusto por lo naif se prolonga hasta nuestros días, en la pintura de este otro Velásquez y en cierta tradición artesanal, análoga a la tradición oral en la literatura. Hoy desde hace un siglo, esa tradición convive con un nuevo arte profesional que, sin embargo, esta en desventaja, porque le apuesta a su independencia, a la visión crítica y a la libertad. Mientras que la artesanía de la paloma, la fruta y la flor apela al gusto general.

La idea de los retrocesos es importante porque lo ya ocurrido puede volver a suceder, aunque sea de otro modo, siempre. Eso podría darnos otra pista para entender por qué los artistas de repente nos comprometemos con el poder, aunque sea el infralunar, achacoso y contaminado y nos convertimos en colaboracionistas. Los retrocesos iluminan también porque, en otros momentos, tomamos la decisión de contradecir al poder, aunque sea peligroso y nos convertimos, de pronto, en rebeldes perseguidos. Cuando no nos queda de otra. ¿Por qué --preguntamos en el tercer párrafo de este ensayo-- se deja instrumentalizar el arte por el poder? ¿Acaso intuimos que podría ser peor? Hasta que entendemos que las cosas "ya no pueden ser peor", porque eso puede suceder también. Y entonces reaccionamos contra lo intolerable y aceptamos las consecuencias. Heredamos esa tradición antigua y moderna, aunque algunos posmodernos se crean desobligados.

\footnotetext{
28 Estamos a punto de publicar un libro nuevo de historia del arte llamado "El Naif en Honduras" de Leticia Oyuela, que ojala nos profundice esa comprensión. Atrás he hablado de la crisis supra $p$.
} 


\section{Moralejas a modo de conclusión}

Como moraleja, yo destacaría que el arte y el artista se tienen que adaptar a su tiempo y circunstancia pero deben aspirar a trascenderlos, con un poquito de astucia. No hay nada de perverso en eso, porque la escritura manda ser más astutos que la serpiente. Valga porque estamos empezando a vivir tiempos difíciles.

Se dice que, cuando regresó de España, después de muchos años de estudios y de práctica profesional de la pintura, nuestro gran pintor Nacional Pablo Zelaya Sierra buscó en 1932 trabajo en el Ministerio de Educación. (Después de todo en ese entonces Diego Rivera pintaba en México lienzos y murales por encargo de Vasconcelos el Ministro de Educación Revolucionario.) Y consiguió, Zelaya, que el Ministro del Cariato le ofreciera un contrato para pintar con brocha gorda una de las escuelas de la capital.

En Honduras, un poco porque se le ha querido asumir como rebeldía y porque el poder no ha comprendido el arte y el beneficio que se le puede derivar del patrocinio del artista, se ha mantenido, en nuestros tiempos, una tradición de arte independiente y contestatario. Un arte que incluso cuestionó y arrinconó al poder publico, como en los cuadros de la etapa de protesta de Ezequiel Padilla o "la poesía política" de Roberto Sosa. Un arte que se enfrentó a la dictadura en los mil novecientos setentas, pero que también denuncia la democracia fingida de las desapariciones, en los ochentas. El Embajador Negroponte asistía a las exhibiciones y compraba las pinturas tenebrosas (una de las cuales cuelga en mi despacho ministerial) alusivas al terror de Estado que patrocinaba y que los demás encubrían: el secuestro, tortura y eliminación selectiva. Muchos artistas se rehúsan aun hoy a colaborar. ¿Tiene que escoger el artista entre la abyección y la confrontación?

Nuestros artistas han superado varias trampas. La nueva literatura de Sosa como la ultima obra de E. Padilla son expresiones que, si bien siguen siendo ferozmente independientes y cuestionadoras y se rehúsan a hacerle concesiones al poder constituido, se reconcilian con su contexto y se ubican mas allá del enfrentamiento. Lo que no es compatible con el arte y con el pensamiento es la pretensión de corrección política. Por su lado el poder público ha madurado en nuestros días. ¿Podrá renunciar al arte oficial, controlado? ¿Decidirse a apoyar la libertad del artista? ¿Cómo apoyar al arte, defenderlo frente a su fragilidad sociopolítica, frente a los distintos poderes? ¡Como comunicarlos mejor, al arte y al poder y conseguir que se apoyen, desde la lucidez de esta historia! Ambos el poder y el arte conllevan 
responsabilidad. Yo entiendo como mi reto personal en el cargo forjar una nueva relación del arte y el poder. Vamos a conservar -mientras se pueda- las condiciones para la creación libre, de calidad, y para el proceso intelectual, de investigación y debate critico. Y cuando no se pueda, sabremos que hacer. Después de todo que, como dice R. Viel, "Washington necesita mas a Hollywood de lo que Hollywood necesita Washington". 